\title{
STRATEGI PENGELOLAAN LEMBAGA PENDIDIKAN ISLAM
}

\author{
Riyuzen \\ riyuzen.tuala@gmail.com \\ Dispora Lampung selatan
}

\begin{abstract}
As a national education subsystem, Islamic education should contribute to building and improving the quality of Indonesian people by creating the best generation (khairunnas / goden generation), which is a generation that excels in science and technology and is able to practice it in daily life. To achieve this goal, Islamic education must be managed optimally through the Islamic Education Institution (LPI). Management of Islamic education institutions whose numbers and shapes are very large certainly requires its own strategy to achieve productivity and quality output. Various concepts and thoughts related to management strategies are urgently needed so that Islamic Education Institutions are no longer regarded as second-class educational institutions that have not been able to fulfill the people's beliefs and needs for quality education. In this paper two management strategies are offered, namely general strategies and specific strategies. In general, strategies are offered based on the Sirozi concept which includes substantive, bottom-up, deregulatory, and cooperative strategies. While specifically applying the management functions of Islamic Education (planning, organizing, implementing / directing and supervising) comprehensively and consistently is considered a smart and futuristic strategic step.
\end{abstract}

Keywords: Islamic Education Institution, Management Strategy

\begin{abstract}
Abstrak
Sebagai subsistem pendidikan nasional, maka pendidikan Islam seharusnya turut berkontribusi dalam membangun dan meningkatkan kualitas manusia Indonesia dengan menciptakan generasi terbaik(khairunnas/goden generation) yaitu generasi yang berprestasi dalam ilmu pengetahuan dan teknologi dan mampu mengamalkannya dalam kehidupan seharihari. Untuk mencapai tujuan tersebut maka pendidikan Islam harus dikelola secara maksimal melalui Lembaga Pendidikan Islam (LPI). Pengelolaan Lembaga pendidikan Islam yang jumlah dan bentuknya sangat banyak tentu memerlukan strategi tersendiri untuk mencapai produktivitas dan out put yang berkualitas. Berbagai konsep dan pemikiran terkait dengan strategi pengelolaan sangat diperlukan agar Lembaga Pendidikan Islam tidak lagi dianggap sebagai lembaga pendidikan kelas dua yang belum mampu memenuhi kepercayaan dan kebutuhan masyarakat akan pendidikan yang berkualitas.Dalam tulisan ini ditawarkan dua strategi pengelolaan yaitu strategi umum dan strategi khusus. Secara umum ditawarkan strategi berdasarkan konsep Sirozi yang meliputi strategi substantive, bottom-up, deregulatory, dan cooperative. Sedangkan secara khusus penerapam fungsi-fungsi Manajemen Pendidikan Islam (perencanaan, pengorganisasian, pelaksanaan/pengarahan dan pengawasan) secara komprehensif dan konsisten dinilai sebagai langkah strategis yang cerdas dan futuristik.
\end{abstract}

Kata kunci: Lembaga Pendidikan Islam, Strategi Pengelolaan 


\section{PENDAHULUAN}

Kesadaran masyarakat Indonesia akan pentingnya pendidikan dalam meningkatkan kualitas SDM menyongsong masa depan yang lebih baik kini makin terasa. Salah satu indikasinya adalah meningkatnya jumlah lembaga pendidikan baik yang dikelola oleh pemerintah maupun pihak swasta. Termasuk diantaranya lembaga pendidikan Islam seperti sekolah/madrasah, pondok pesantren bahkan kini bermunculan modifikasi sekolah/madrasah dengan sistem pondok yang disebut dengan "boarding school" .Pesatnya pertumbuhan secara kuantitas tersebut harus diikuti pula dengan peningkatan mutu pengelolaan nya agar segenap proses yang dijalankan memiliki efektifitas dan efisiensi yang tinggi dan dapat menghasilkan out put yang sesuai dengan kebutuhan masyarakat.

Saat ini mutu menjadi menjadi perhatian utama banyak orang baik secara individu maupun dalam suatu organisasi. Mereka menganggap bahwa sesuatu yang berkualitas akan banyak dibutuhkan dan karena nya memiliki peluang untuk memenangkan kompetisi ditengah-tengah kehidupan masyarakat yang semakin maju(Fathurrohman, 2012)terkaitpentingnyamutuini Casteter menyatakansebagai berikut;

"The goals of the human resources function in any educational system are to attract, develop retain, and motivate personal in order to (a) achieve the system's purposes, (b) assist members in satisfying position and group performance standards, (c) maximize personal career development, and (d) reconcile individual an organizational objectives. These goals must be translated in to operational term to give direction to those responsible for their implementation." (Casteter, 1992)

Sebuah Lembaga Pendidikan Islam harus bermutu untuk menjaga eksistensinya dan bertahan ditengah kompetisi yang sangat ketat sekarang ini. Jadi mutu merupakan hal yang wajib dan harus ada dalam lembaga pendidikan.(Arcaro, 2007)Agar mutu pendidikan tersebut dapat dicapai maka lembaga pendidikan harus mampu mengoptimalkan fungsi dan peran seluruh sumber-sumber daya pendidikan baik sumber daya manusia maupun sarana dan prasarana fisik lainnya yang dimiliki.(Chotimah \& Fathurrohman, 2014) 
Pendidikan Islam memiliki visi melahirkan manusia sholeh dalam ilmu, amal dan akhlaknya. Sedangkan misi yang ingin dicapai adalah pertama, mendidik dan mengajarkan ajaran Islam secara kaffah (komprehenshif) sehingga peserta didik mengetahui dan memahami sekaligus memiliki keasadaran yang tinggi untuk mengamalkannya. Pendidikan Islam tidak ingin terjebak pada metode formalitas belaka dengan konsentrasi hanya pada upaya transfer ilmu secara teoritis semata, menghasilkan siswa yang pandai menghafal ajaran Islam tetapi tidak memiliki sikap dan prilaku yang Islami (manusia yang sholeh). Kedua, memberikan bekal agar para siswa mampu berpartisipasi dan berkontribusi seberapapun besar kecilnya dalam kehidupan sosial. serta memiliki kemampuan berkompetisi dengan tetap berpijak pada rambutambu ajaran Islam. Menurut Abuddin Nata, Cita-cita besar yang ingin dicapai melalui Pendidikan Islam adalah menjadikan ajaran Islam sebagai landasan yang kuat dan membumi dalam segala sendi kehidupan.(Nata, 2010) pendidikan merupakan proses transformasi dan internalisasi ilmu pengetahuan dan nilai-nilai Islam pada peserta didik melalui penumbuhan dan pengembangan potensi fitrahnya untuk mencapai keseimbangan dan kesempurnaan hidup dalam segala aspeknya.

Nilai-nilai Islam, maksudnya adalah nilai-nilai yang terkandung dalam praktek pendi- dikan harus mengandung nilai Insaniah dan Ilahiyah. Yaitu: a) nilai-nilai yang berdasarkan dari sifat-sifat Allah Asmaul Husna yakni nama-nama yang indah yakni idealitas manusia yang disebut fitrah, yang harus dikembangkan. b) Nilai yang bersumber pada hukum-hukum Allah, yang selanjutnya di dialogkan pada nilai insaniah. Nilai ini merupakan nilai yang terpancar dari daya cipta, rasa dan karsa manusia yang tumbuh sesuai dengan kebutuhan manusia.(Sada, 2015) Dalam konteks upaya meningkatkan kualitas Sekolah/Madrasah dan LPI lainnya, maka peran dan kontribus Ilmu Manajemen Pendidikan Islam sangat besar dan strategis. Sebagai disiplin ilmu baru, maka Ilmu Manajemen Pendidikan Islam menawarkan konsep pembinaan dan pengelolaan suatu Lembaga Pendidikan Islam dengan dua prinsip dasar yakni keberhasilan meraih mutu berkeunggulan umum melalui optimalisasi fungsi-fungsi manajemen dan meraih keunggulan berbasis ajaran Islam (Al-Qur'an dan Al-Hadist). Kedua prinsip dasar tersebut harus berjalan beriringan, komprehensif, terpadu dan tidak parsial. 
Tujuan akhir dari pengelolaan suatu lembaga pendidikan Islam tidak lain adalah menjadikan Tujuan akhir dari pengelolaan Sekolah/Madrasah dan LPI lainnya adalah menjadikan LPI sebagai media utama dalam mempelajari ilmu keagamaan dan ilmu umum agar peserta didik/santri dapat menjadi Generasi Terbaik (Khairu Ummah). Melalui prinsip manajemen seperti ini diharapkan program pendidikan dan pembelajaran dapat berjalan dan menghasilkan Sekolah/Madrasah/Pondok Pesantren yang berintegritas tinggi, berkemajuan, berkeunggulan, berdaya saing serta mampu menghasilkan lulusan sebagai generasi yang banyak memberi manfaat bagi sesama dimanapun ia berada.

Berdasarkan penelitian terdahulu, telah dilakukan beberapa penelitian dalam pengelolaan lembaga pendidikan dalam rangka pencapaian tujuan pendidikan dan strategi peningkatan mutu pendidikan (Ardimen, 2012; Fathurrohman, 2012; Himayaturohmah, 2017; Khadijah, 2015; Khojir, 2011; Priyatna, 2016; Rohman, 2014; Rozi, 2016; Sodiah, 2016; Sulistyorini, 2012; Tanu, 2016)

Berdasarkan penelitian yang telah dilakukan sebelumnya, keterbaruan dalam penelitian ini terletak pada bagaimana strategi pengelolaan lembaga pada pendidikan Islam.

\section{METODE PENELITIAN}

Jenis penelitian yang digunakan adalah model penelitian kualitatifdengankajialiteraatur. Penelitian kualitatif bertujuan memperoleh gambaran seutuhnya mengenai suatu hal menurut pandangan manusia yang diteliti. Penelitian kualitatif berhubungan dengan ide, persepsi, pendapat, atau kepercayaan orang yang diteliti; kesemuanya tidak dapat diukur dengan angka

\section{HASIL KAJIAN DAN PEMBAHASAN}

\section{Lembaga Pendidikan Islam dan Tantangannya}

Lembaga Pendidikan Islam ialah suatu bentuk organisasi yang diadakan untuk mengembangkan lembaga-lembaga Islam melalui upaya/program kegiatan yang tersusun dengan rapi dan teroganisir dengan baik mengikuti khirarki dan aturan tertentu untuk mencapai tujuan yang telah ditetapkan.(Kurikulum, 2016a) 
Dengan demikian dapat dikatakan bahwa Lembaga Pendidikan Islam merupakan suatu wadah/media/organisasi tempat dimana pendidikan Islam diselenggarakan. Lembaga ini memiliki struktur organisasi dan pembagian tugas/wewenang dan tanggung jawab yang jelas, tertata dengan baik sehingga memungkinkan terciptanya suasana kondusif yang mendukung terlaksananya proses pendidikan dan pembelajaran Agama Islam dengan efektif sesuai dengan karakteristik dan tugas masing-masing, seperti sekolah/madrasah.

Berdasarkan sejarah, terbentuknya LPI bermula dari difungsikannya rumah AlArqam bin Abi Al-Arqam (Daar Al-Arqam) sebagai tempat berkumpulnya kaum muslimin dibawah kepemimpinan Rasulullah. Materi yang diajarkan pada waktu itu adalah tentang ayat-ayat al-Qur'an yang diturunkan Allah SWT melalui Malaikat Jibril. Proses pembelajaran berlangsung dengan menggunakan metode ceramah dan praktik langsung yang dipimpin Rasulullah SAW. Berbagai kandungan ayat-ayat al-Qur'an dipelajari bersama disertai dengan penjelasan dan diskusi.Jika dirunut kebelakang sejarah terbentuknya LPI nampak jelas bahwa terbentuknya LPI didasarkan atas kebutuhan ummat yang bersatu padu dengan Ruhul Islam ( jiwa ke Islaman). Ummat Islam pada waktu itu telah menyadari akan pentingnya suatu wadah atau organisasi yang akan menjadi media pendidikan dan pembelajaran ajaran Islam secara menyeluruh.

Dalam perkembangannya kemudian, LPI telah menetapkan prinsip-prinsip untuk mempertahankan eksistensi dan kontribusinya ditengah-tengah kehidupan global yang sangat dinamis. Prinsip-prinsip tersebut antara lain(Kurikulum, 2016b)

a. Prinsip pembebasan manusia dari ancaman kesesatan yang menjerumuskan manusia pada api neraka (QS. At-Thamrin:6).

b. Prinsip pembinaan umat manusia menjadi hamba-hamba Allah yang memiliki keselarasan dan keseimbangan hidup bahagia dunia dan akherak (QS. AlBaqarah: 201; Al-Qashash: 77).

c. Prinsip pembentukan kepribadian manusia yang memancarkan sinar keimanan yang kaya dengan ilmu pengetahuan, yang satu sama lain mengembangkan hidupnya untuk menghambakan diri pada Khaliknya (QS. Al Mujadilah: 11).

d. Prinsip amar ma'ruf nahi dan munkar dan membebaskan manusia dari belenggu-belenggu kenistaan (QS. Ali-Imran: 104, 110). 
e. Prinsip pengembangan daya pikir, daya nalar, dan daya rasa sehingga dapat menciptakan anak didik yang kreatif dan dapat memfungsikan daya cipta, rasa, dan karsa.

Prinsip LPI bersifat relatif tetap dan ideal. Artinya jika dlaksanakan secara konsisten dan konsekuen maka pendidikan tersebut dapat menghasilkan generasi yang kuat, kokoh dan mulia. Hal tersebut sejalan dengan prinsip pendidikan(Wahyuni, 2014)

1. Belajar adalah kewajiban bagi setiap orang. Tujuannya adalah agar manusia berubah menjadi lebih baik. Lebih baik pengetahuan dan wawasannya, lebih banyak pengalamannya, lebih baik akhlak dan kepribadiaanya, lebih baik prilakunya dalam kehidupan bersama, dan lebih baik lagi karyanya yang dapat bermanfaat untuk orang banyak. Semua manusia mempunyai peluang yang sama tanpa perbedaan untuk mendapatkan pendidikan dan pembelajaran dengan baik, dan inilah yang merupakan prinsip pendidikan untuk semua (Education For All).

2. Prinsip Pendidikan sepanjang masa ( Long Life Education). Prinsip ini menekankan bahwa belajar dapat dilakukan sepanjang masa, selagi manusia masih sehat dan kuat. Belajar dapat dilakukan dimana saja, kapan saja dan dengan siapa saja sepanjang dapat memberikan perubahan yang lebih baik bagi dirinya.

3. Prinsip Pendidikan Berwawasan Dunia. Prinsip ini menekankan bahwa menuntut ilmu pengetahuan dan teknologi itu tidak hanya dilakukan di negeri sendiri tetapi juga terbuka luas di berbagai belahan dunia. Hal tersebut dimaksudkan agar setiap individu yang belajar dapat menganalisis perbandingan konten dan metode pembelajaran di berbagai tempat lain sehingga kemudian dapat menarik kesimpulan yang tepat tentang sesuatu hal.

4. Prinsip Pendidikan Integralistik Prinsip ini mengingatkan kepada kita bahwa ilmu agama (addinul Islam) sesuangguhnya tidak dapat dipisahkan dengan ilmu umum. Bahkan keduanya saling membutuhkan dan saling melengkapi.

5. Prinsip Pendidikan sesuai fitrah manusia. Manusia dilahirkan membawa bakat dan potensi lainnya yang satu sama lain mungkin ada kesamaan dalam beberapa hal, tetapi mungkin juga berbeda dalam hal yang lain. Oleh karenanya pendidikan dan pembelajaran harus dirancang berdasarkan bakat, minat dan potensi peserta 
didik tersebut. Program pembelajaran (kurikulum) harus dirancang seirama dengan pertumbuhan dan perkembangan manusia.

6. Prinsip pendidikan yang demokratis dan manusiawi. Prinsip ini menekankan bahwa pendidikan dan pembelajaran harus dijalankan diatas prinsip keterbukaan, menyenangkan dan menghargai perbedaan setiap manusia. Pendidikan dan pembelajaran tidak boleh membelenggu kebebasan setiap individu untuk mengekspresikan berbagai potensi diri sepanjang tidak mengganggu kepentingan orang lain. Prinsip ini mengakui kekurangan dan kelebihan setiap orang dalam belajar. Dan karenanya setiap peserta didik harus mendapatkan perlakuan yang sebaik-baiknya.

7. Prinsip pendidikan yang ilmiah. Pendidikan dan pembelajaran harus dijalankan atas dasar tiori, fakta dan data yang dapat dipertanggungjawabkan secara ilmiah. Siapapun yang terlibat dalam proses pendidikan dan pembelajaran seyogyanya menghindarkan diri dari materi, informasi, data, yang sumbernya tidak jelas (tidak valid ) dan tidak dapat dipertanggungjawabkan.

8. Prinsip pendidikan yang berkualitas. Prinsip ini menekankan bahwa pendidikan yang bermutu hanya akan dapat dicapai apabila ditangani secara profesional oleh sumber daya manusia yang berkualitas pula. Penyelenggaraan pendidikan di berbagai jenjang harus mengutamakan mutu agar lulusannya memiliki daya kompetitif yang tinggi.

Menurut Muhaimin(Muhaimin \& Mujib, 1993) Lembaga pendidikan Islam secara umum bertujuan untuk meningkatkan keimanan, pemahaman, penghayalan dan pengalaman peserta didik tentang agama Islam, sehingga menjadi manusiamuslim yang beriman dan bertakwa kepada Allah SWT serta berakhlak mulia dalam kehidupan pribadi, bermasyarakat berbangsa dan bernegara.

Pendidikan dan pembelajaran yang diselenggarakan di Sekolah-Sekolah/Madrasah diarahkan pada pembinaan dan pengembangan ketiga aspek utama dalam diri peserta didik yaitu aspek kognitif yang berguna untuk mempelajari seluruh ciptaan Allah SWT dan menganalisisnya untuk menguatkan keyakinan dan memperkokoh ketaatan beribadah kepada Allah SWT. Pada aspek afektif, peserta didik dibina untuk dapat mengimplementasikan ajaran Islam dalam bentuk amal sholeh. Semangat beramal dan 
beribadah hanya kepada Allah semata menjadi point penting pada aspek ini. Pada aspek psikomotorik, peserta didik diharapkan dapat beramal nyata melalui karya-karya terbaik masing-masing.

Seiring waktu jumlah dan bentuk LPI semakin banyak Wajarlah jika penanganan dan pembinaannya kian rumit dan karenanya membutuhkan perhatian yang lebih baik lagi. Dalam perkembangannya banyak tantangan yang harus dihadapi oleh para pengelola LPI. Tantangan tersebut bersifat internal dan eksternal. Jika dilihat dari sisi internal, pada mula nya kehidupan ummat Islam masih sangat dekat dengan ajaran Islam (Al-Qur'an dan Al-Hadts). Dalam kehidupan sehari-hari semangat memperjuangkan ajaran Islam begitu kuat. Demikian pula secara eksternal ummat Islam masih realtif aman dari gangguan, ancaman, Kini tantangan itu mulai berbeda. Pendidikan Islam mulai dihadapkan pada tantangan, ancaman bahkan serangan pahampaham sesat di luar Islam. Jika hal ini tidak disadari atau bahkan dibiarkan begitu saja, maka Ummat dan ajaran Islam akan mengalami kehancuran yang menyedihkan. Kemajuan Ilmu Pengetahuan dan Teknologi (IPTEK) yang merubah budaya global bukan saja sebagai barokah Allah yang diturunkan kepada bangsa ini tetapi juga sekaligus sebagai ancaman menakutkan bagi kehancuran seluruh generasi ummat manusia khususnya ummat Islam bila salah dalam mensikapinya. Pertumbuhan informasi dan skala distribusinya yang semakin luas tanpa batas dapat mengubah cara pandang manusia terhadap hubungan timbal baliknya kepada sang pencipta. Serangan terakhir dapat pula datang dari prilaku ummat Islam itu sendiri yang tidak lagi kokoh dan teguh dalam memeluk dan mengamalkan ajaran Islam dalam kehidupan seharihari.(Rusmaini, 2014)

Menurut Cece Wijaya dalam Akmal Hawi(Hawi, 2005)menjelaskan terdapat enam tantangan bagi Lembaga Pendidikan Islam sebagai berikut :

a. Kuatnya pengaruh kebijakan formal pemerintah terhadap pengelolaan pendidikan. Sekolah/madrasah dan LPI lainnya harus bisa menyesuaikan diri dengan cerdas dan tetap teguh mempertahankan identitas keagamaannya.

b. Dibidang Kebudayaan, lahir dan makin menguatnya budaya materialistik dan hedonistik. Hal ini harus dihadapi dengan sikap selektif dan tetap mengacu pada budaya hidup yang Islami.

c. Kemajuan dibidang IPTEK mengandung dua konsekuensi, Disatu sisi melahirkan 
berbagai kemudahan hidup, tetapi disi lain dapat menghancurkan peradaban dan tatanan kehidupan manusia jika disalah gunakan. IPTEK harus diarahkan pada terbentuknya manusia mandiri, produktif, kompetititf dan solutif.

d. Perkembangan ekonomi suatu bangsa akan mempengaruhi pembangunan pendidikan. Pertumbuhan sekolah/madrasah tidak bisa dilepaskan dari kondisi perekonomian yang sedang berkembang. Agar sekolah/madrasah dan LPI lainnya dapat eksis dan produktif tidak ada jalan lain kecuali harus cerdas dan pandai menyesuaikan diri dengan tantangan dibidang ekonomi dengan cara menciptakan kurikulum yang adaftif.

e. Berubahnya pola dan gaya hidup di masyarakat mengharuskan sekolah/madrasah dan LPI lainnya untuk berperan sebagai pemberi arah yang jelas serta menjadi pencerah mental spiritual masyarakat. Karena kondisi dalam sistem kehidupan sosial seringkali mengalami ketidakpastian tujuan.

f. Terjadi konflik dan pertarungan nilai antara nilai moral-spiritual termasuk nilai etika terhadap budaya yang membawa nilai materialistik-hedonistik di tengah-tengah kehidupan masyarakat. Apapun yang terjadi maka sekolah/madrasah danj LPI lainnya harus tetap memposisikan diri dan memegang teguh ajaran Islam. LPI harus memposisikan diri sebagai penjaga pintu nilai-nilai spiritual-moral di masyarakat.

g. Munculnya inkonsistensi dalam pengamalan ajaran Islam dikalangan ummat Islam menjadi tantangan serius bagi Lembaga Pendidikan Islam maupun pendidikan berwawasan Islam(Majid, 2012)

Tantangan lainnya menurut Syahrin Harahap adalah popularitas sekolah umum makin meningkat. Sedangkan sekolah Islam bagi sebagian masyarakat kita dianggap sekolah cadangan ( alternatif bila tidak diterima di sekolah umum) Argumen klasiknya adalah bahwa sekolah umum dianggap lebih mampu bersaing dalam menyiapkan lulusan yang berkualitas dibandingkan dengan sekolah Islam atau sekolah berwawasan Islam. Meskipun akhir-akhir ini mulai muncul sekolah Islam atau pun sekolah umum berwawasan Islam yang mampu menunjukkan prestasinya, namun jumlahnya masih relatif sedikit.(Harahap, 1998) 


\section{Strategi Pengelolaan Lembaga Pendidikan Islam (LPI)}

Kompleksnya permasalaham pengelolaan Lembaga Pendidikan Islam tidak berarti mematahkan semangat kita untuk terus berupaya maksimal mencari dan mencoba berbagai solusi alternatif agar LPI dapat keluar dari "zona masalah" sebagaimana telah dibahas pada bagian awal pembahasan. Tingginya Ekspektasi akan meningkatnya kualitas sekolah/madrasah/LPI lainnya dari sisi tata kelola administrasi, input dan proses yang tentu juga sekaligus meningkatnya pemahaman dan pengamalan ajaran Islam di kalangan stake holders LPI (out put dan out comes) harus menjadi penyemangat semua pihak dalam pengelolaan LPI.

Terdapat beberapa strategi alternatif untuk menjawab berbagai tantangan pengelolaan LPI. Yaitu strategi Umum dan strategi khusus. (Qomar, 2007) Dalam strategi umum misalnya

1) Merumuskan cita-cita, program, serta tujuan yang ingin dicapai lembaga secara jelas Langkah selanjutnya adalah berupaya maksimal merealisasikan nya melalui kegiatan-kegiatan riil sehari-hari.

2) Membangun kepemimpinan dan budaya organisasi yang baik dan profesional. Menyiapkan pendidik yang benar-benar berjiwa pendidik, memahami dan meneladani ajaran Islam sehingga mengutamakan tugas-tugas pendidikan dan pembelajaran untuk keberhasilan peserta didiknya. Merumuskan dan menyususn materi pembelajaran sesuai dengan perkembangan peserta didik dan kebutuhan masyarakat.

3) Menggali potensi-potensi keuangan dan mengembangkannya dengan kreatif. Meningkatkan promosi untuk membangun citra (image building)

4) Membangun kerjasama (networking) baik ditingkat daerah nasional maupun internasional.

5) Sikap optimis, peduli, aktif dan kreatif dalam menghadapi berbagai tantangan di masyarakat pada umumnya dan di lingkungan pendidikan khususnya.

Sedangkan menurut Tilaar dalam Mujamil Qomar bahwa pengelolaan lembaga pendidikan Islam sebaiknya meliputi empat langkah bidang prioritas berikut ini:

1) Peningkatan kualitas,

2) Pengembangan inovasi dan kreativitas,

3) Membangun jaringan kerja sama (networking), dan 
4) Pelaksanaan otonomi daerah.

Sejalan dengan beberapa pandangan di atas,maka empat strategi yang dikemukaan Sirozi(Alim, 2010)layak untuk diterapkan dalam meningkatkan efektivitas dan efisiensi Sekolah/Madrasah dan LPI lainnya. Keempat strategi tersebut adalah :

Pertama, strategi substantive; sekolah-sekolah Islam seperti madrasah, pondok pesantren dan LPI lainnya perlu menyajikan program-program yang komprehensif meliputi aspek Kognitif (pemahaman), afektif (penerimaan atau sikap) dan psikomotorik (pengalaman atau keterampilan). Proses pendidikan dan pembelajaran menurut UNESCO harus dapat membantu peserta didik untuk dapat belajar bagaimana mergetahui (How to know), bagaimana berbuat/melakukan sesuatu (How to do), bagaimana menjadi diri sendiri ( How to be), bagaimana hidup bersama berdampingan dengan orang lain ( How to live together), dan bagaimana mengenal ciptaan Tuhan (How to know Gods creation) Bila semua aspek dan kemampuan ini disajikan secara terpadu, maka para lulusan /out put LPI diharapkan memiliki keseimbangan antara kualitas iman, ilmu dan amal.

Kedua, strategi bottom-up;Pertumbuhan dan perkembanganLPI harus dimulai dari bawah. Artinya konsep dan rancang bangun kurikulum serta berbagai kebijakan pengembangan kualitas SDM dan sarana fisik lainnya harus disesuaikan dengan kebutuhan, potensi dan cita-cita masyarakat. Masyarakat harus dilibatkan sejak dari tahap perencanaan, pelaksanaan sampai pada tahap evaluasi. Konsep kebersamaan yang dibangun dari bawah inilah yang diyakini mampu menumbuhkan sikap kepedulian yang tinggi (concern), rasa memiliki ( sense of belonging), dan rasa turut bertanggung jawab (sense of responsibility) atas prestasi yang dicapai. Keikutsertaan masyarakat ini dapat saja direfresentasikan oleh Komite Sekolah/Madrasah. Organisasi ini perlu bekerja sama bahu membahu guna memajukan kualitas sekolah.

Ketiga, strategi deregulatory; Sekolah-sekolah Islam/madrasah dan LPI lainnya seharusnya diberi kebebasan untuk berkreasi dan berimprovisasi terhadap programprogram pembinaan dan pengembangan, tidak terlalu terpaku dan kaku pada aturan umum yang di buat oleh pemerintah. Dengan strategi seperti ini akan menjadikan LPI institusi yang mandiri dan memiliki peluang maju yang lebih besar sehingga mampu tumbuh menjadi lembaga pendidikan alternatif. Sekolah/madrasah dan LPI lainnya jika ingin mendapatkan kepercayaan yang lebih besar dari masyarakat, maka harus bisa 
memposisikan diri sebagai lembaga pelopor perubahan yang mengedepankan kualitas dan bukan sekedar kuantitas belaka..

Keempat, strategi cooperative; Dalam proses pembinaan dan pengembangannya, maka sekolah/madrasah dan LPI lainnya harus bisa bekerja sama, (berkolaborasi) dan memberdayakan semua potensi dan sumber daya yang ada baik dari internal maupun dari lingkungan sekitarnya. Perlu dibangun kerjasama dan kemitraan baik dengan pribadi-pribadi yang berkompeten maupun dengan lembaga lainnya yang relevan dan mendukung. Kerjasama semacam ini dinilai dapat membantu sekolah/madrasah dan LPI lainnya untuk meningkatkan kemampuan finansial dan memberi masukan untuk kemajuan lembaga.

\section{a. Strategi Khusus : Pendekatan Manajemen Pendidikan Islam}

Pendekatan Fungsi-fungsi Manajemen Pendidikan Islam dinilai merupakan langkah yang tepat dalam rangka optimalisasi pengelolaan LPI. Fungsi-fungsi manajemen pendidikan Islam sebagaimana dikemukakan oleh Mahdi bin Ibrahim sebagai berikut:(Ibrahim, 1997)

\section{Fungsi Perencanaan (Planning)}

Perencanaan adalah suatu langkah sistematis yang dipersiapkan sebelum melakukan suatu pekerjaan untuk memudahkan mencapai tujuan yang telah ditetapkan.Langkah awal tersebut dapat berupa pemikiran, konsep, dan metode yang akan mendukung keberhasilan pelaksanaan suatu kegiatan. Islam menganjurkan agar setiap orang membuat suatu perencanaan ketika akan melakukan sesuatu pekerjaan sebagaimana yang disebutkan di dalam QS. Al-Hasr : 18, yang berbunyi :

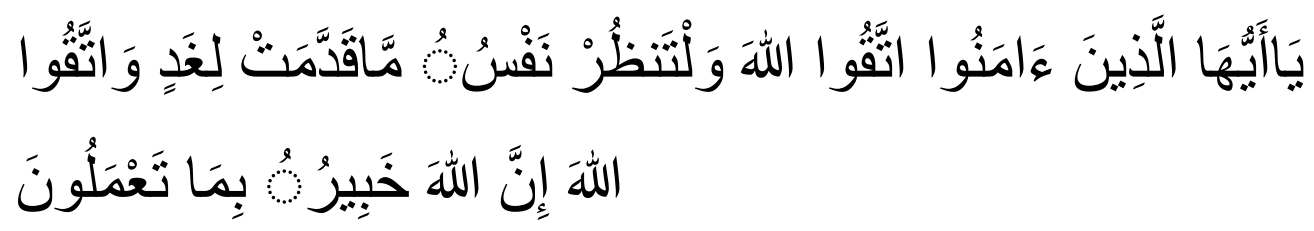

Artinya: Hai orang-orang yang beriman, bertakwalah kepada Allah dan hendaklah Setiap diri memperhatikan apa yang telah diperbuatnya untuk hari esok (akhirat); dan bertakwalah kepada Allah, Sesungguhnya Allah Maha mengetahui apa yang kamu kerjakan. 
Ayat tersebut menegaskan kepada kita bahwa untuk menyambut masa depan yang lebih baik harus ada persiapan dan diperlukan perencanaan yang matang agar tujuan yang ditetapkan dapat tercapai dengan baik. Terdapat beberapa hal yang harus diperhatikan dalam menyusun suatu perencanaan antara lain : pertama adalah merumuskan tujuan yang ingin dicapai, kedua, merumuskan kekuatan (potensi) dan kelemahan yang dimiliki, ketiga, mengidentifikasi dan merumuskan masalah dan potensi masalah yang ada, keempat,, merumuskan cara mengatasi masalah (metode dan strategi), kelima, menetapkan faktor pendukung dalam mengatasi masalah yang ada, keenam, mempertimbangkan resiko yang mungkin terjadi atas langkah-langkah yang akan diambil.

Perencanaan dalam Pendidikan Islam harus berorientasi pada dua tujuan sekaligus, yaitu kesuksesan, kebahagian dan kemulyaan hidup di dunia dan kebahagian sejati yang kekal abadi di akherat. Oleh karenanya maka perencanaan pembangunan dan pengembangan LPI termasuk pada tataran praktik pendidikan dan pembelajarannya tidak boleh mengutamakan salah satu saja tetapi harus mengedepankan prinsip keseimbangan dunia dan akherat. Setiap langkah perencanaan terlebih dahulu harus dikonsultasikan dan tidak boleh bertentangan dengan nilai-nilai dalam ajaran Islam. Tujuannya tidak lain adalah semata-mata untuk mendapatkan ridho dan barokah Allah SWT. Dan menghindarkan diri dari murka dan azab Allah SWT.Sedangkan menurut Ramayulis, terdapat 4 hal yang akan menentukan keberhasilan perencanaan dalam Manajemen Pendidikan Islam (Ramayulis, 2008)

a) Penentuan prioritas agar pelaksanaan pendidikan berjalan efektif, prioritas kebutuhan agar melibatkan seluruh komponen yang terlibat dalam proses pendidikan, masyarakat dan bahkan murid.

b) Penetapan tujuan sebagai garis pengarahan dan sebagai evaluasi terhadap pelaksanaan dan hasil pendidikan

c) Formulasi prosedur sebagai tahap-tahap rencana tindakan.

d) Penyerahan tanggung jawab kepada individu dan kelompok-kelompok kerja. 
Berdasarkan beberapa pendapat di atas, nampak jelas bahwa perencanaan adalah suatu langkah awal yang sangat penting yang akan menentukan kegiatan berikutnya. Oleh karena itu setiap kali akan melaksanakan suatu program atau kegiatan terlebih dahulu harus dibuat langkah-langkah awal perencanaannya sebagai pedoman melaksanakan kegiatan berikutnya. Suatu kegiatan yang tidak direncanakan dengan baik memiliki peluang yang lebih besar untuk gagal. Demikian pula sebaliknya.

\section{Fungsi Pengorganisasian (organizing)}

Inti dari pengorganisasian adalah pembagian tugas dan wewenang kepada masingmasing bagian dalam suatu organisasi yang tergambarkan dalam suatu struktur organisasi yang sesuai dengan tujuan yang ingin dicapai. Di dalam pendidikan Islam Pembagian tugas dan wewenang tersebut harus dilakukan dengan amanah dan profesional. Artinya tugas yang diberikan kepada seseorang atau pada suatu kelompok kerja harus sesuai dengan kompetensi yang dimilikinya dan bukan semata-mata karena hubungan tertentu. Artinya penugasan harus disesuaikan dengan kemampuan orang yang diberi tugas agar tugas yang diberikan dapat dilaksanakan dengan baik.

Prinsip ini sudah ditegaskan di dalam Hadits Nabi Muhammad SAW yang artinya :"Apabila suatu urusan diserahkan kepada bukan ahlinya, maka tunggulah saat kehancurannya" (Hadits shahih riwayat al-Bukhari).

Di dalam suatu organisasi tentu ada pemimpin dan orang yang dipimpin. Kedua bagian ini harus berjalan sesuai dengan tugas pokok dan fungsinya masingmasing.Didalam pengorganisasian, dituntut adanya komunikasi dan koordinasi yang baik antar individu dalam kelompok. Inilah yang menjadi kunci dalam kegiatan pengorganisasian ini. Seluruh peraturan dan ketentuan-ketentuan lainnya yang telah ditetapkan dalam suatu organisasi harus dipatuhi dan dilaksanakan dengan penuh kedisiplinan dan rasa tanggung jawab. Dalam melaksanakan suatu tugas/kegiatan organisasi maka prinsip musyawarah yang memberi peluang dan ruang kebebasan berpendapat sesuai dengan kondisi dan kebutuhan masing-masing merupakan hal yang penting. Pembagian tugas kerja yang tertuang dalam tugas pokok dan fungsi (TUPOKSI) oragnisasi dilaksanakan berdasarkan bagian-bagian/organ-organ dalam suatu struktur organisasi. Tujuannya adalah agar secara keseluruhan kinerja organisasi dapat berjalan secara efisien dan efektif. Tupoksi yang telah diatur dalam suatu 
organisasi sekaligus menggambarkan hak dan kewajiban masing-masing anggota/bagian. Pembagian tugas dan wewenang dalam Lembaga Pendidikan Islam juga harus memperhatikan prinsip-prinsip nilai moral dan etika seperti persamaan dalam mematuhi dan melaksanakan peraturan yang berlaku, adil dan terbuka serta musyawarah dengan memegang teguh kebijakan dalam kebajikan.

Uraian di atas memberikan pemahaman kepada kita bahwa pengorganisasian pada hakekatnya adalah pembagian tugas untuk mengerjakan suatu jenis pekerjaan karena tidak bisa jika dilakukan hanya oleh diri sendiri atau hanya oleh satu atau dua orang saja melainkan oleh beberapa orang dalam suatu kelompok/tim. Untuk dapat melaksanakan tugas-tugas tersebut harus ada pemberian kewenangan kepada masing-masing bagian. Pembagian tugas dan wewenang tersebut dilakukan sesuai dengan kemampuan (kompetensi) yang diberi tugas agar roda organisasi dapat berjalan dengan efektif, efisien dan produktif. Alur kerja masing-masing bagian dalam suatu organisasi dapat dilihat berdasarkan struktur organisasi yang telah ditetapkan. Dan semua bagian-bagian dalam organisasi harus taat dan disiplin melaksanakan tugas berdasarkan TUPOKSI nya dalam suatu struktur organisasi.

\section{Penggerakan dalam Pendidikan Islam}

Fungsi penggerakan dalam Manajemen Pendidikan Islam merupakan suatu cara menggerakkan orang-orang/bagian-bagian yang ada dalam suatu organisasi agar mereka mau melaksanakan TUPOKSI nya masing-masing. Upaya menggerakkan sekelompok orang dalam suatu organisasi bukan hal yang mudah. Sebab belum tentu semua anggota dalam suatu organisasi memiliki cara pandang yang sama terhadap suatu tugas atau suatu masalah yang dihadapi. Oleh karena itu diperlukan seorang pemimpin yang memiliki kemampuan mempengaruhi dengan cara memberi motivasi yang baik, mampu berkomunikasi dengan efektif, memiliki kemampuan dan kemauan berkoordinasi dengan semua bagian-bagian dalam organisasi. Penggerakan dalam Pendidikan Islam tidak hanya ditujukan untuk agar organisasi mendapatkan keuntungan atau keberhasilan program duniawi semata tetapi harus juga mempertimbangkan ridha Allah SWT. Upaya penggerakan dalam pendidikan Islam harus terimplementasikan dengan baik dalam proses pendidikan dan pembelajaran di sekolah/madrasah. Terdapat beberapa langkah yang perlu dilakukan dalam upaya penggerakan Pendidikan Islam : 
1. Mencari dan menempatkan orang-orang yang memiliki kecakapan yang tinggi untuk melaksanakan suatu kegiatan

2. Memberikan penjelasan tentang tujuan pendidikan Islam yang ingin dicapai

3. Memberikan kewenangan kepada seluruh komponen organisasi sesuai dengan kebutuhan

4. Meneguhkan keyakinan yang kuat kepada seluruh komponen organisasi dalam upaya mencapai tujuan yang diharapkan.

Untuk melaksanakan keempat langkah tersebut dibutuhkan seorang pemimpin LPI yang memiliki pandangan jauh kedepan (Vuturistik), menghargai nilai-nilai kemanusiaan dan memiliki ide/gagasan-gagasan cemerlang. Memiliki semangat dan jiwa pengabdian yang tulus dan tinggi, menghormati dan menghargai kelebihan dan kekurangan setiap anggota serta memiliki rasa kasih sayang dan tanggung jawab terhadap semua elemen organisasi. Penggerakan juga dapat dimaknai sebagai upaya memberikan pengarahan kepada anggota organisasi agar mereka dapat melaksanakan tugas secara efektif.

Didalam memberikan pengarahan hal penting yang harus diperhatikan adalah kejelasan perintah, larangan, himbauan, dan konsekuensi yang akan diterima manakala ada arahan yang dilanggar. Didalam memberikan pengarahan, maka prinsip kejelasan, keteladanan dan kesesuaian dengan kemampuan anggota akan sangat menentukan efektivitas arahan yang diberikan.

Di dalam Islam telah dicontohkan tentang kepemimpinan Rasulullah SAW yang sangat efektif karena beliau memiliki keteladanan sikap dan prilaku yang luar biasa. "Sesungguhnya didalam diri Rasulullah terdapat suri tauladan yang baik". Keteladanan melahirkan kepatuhan, motivasi kerja yang tulus dan ikhlas serta rasa tanggung jawab untuk melaksanakan suatu tugas dengan senang hati.

Pengarahan dapat dilakukan dimulai dengan memberikan orientasi (informasi) yang jelas tentang suatu kegiatan yang akan dilaksanakan, memberikan perintah yang jelas dan terukur, dan memberikan kewenangan kepada anggota sesuai dengan tugas pokok dan fungsinyanya dalam organisasi. 


\section{Pengawasan dalam Pendidikan Islam}

Fungsi pengawasan dalam manajemen pada hakekatnya adalah pengendalian melalui penilaian atas pelaksanaan suatu kegiatan, kesesuaian kegiatan dengan perencanaan dan tingkat ketercapaian suatu kegiatan berdasarkan target yang telah ditetapkan. Rentang waktu pengawasan dapat dilakukan sebelum pelaksanaan, pada saat pelaksanaan dan setelah pelaksanaan suatu program/kegiatan. Pengawasan meliputi kondisi objektif di dalam dan diluar organisasi. Berbagai fenomena dan realitas dinilai, dianalisis, dan kemudian dikoreksi dengan acuan standar pencapaian tertentu. Hasilnya kemudian dapat menjadi bahan perbandingan dengan target yang ingin dicapai oleh suatu organisasi.

Didalam dunia pendidikan, pengawasan lebih dititik beratkan pada upaya pengendalian mutu dimulai dari masukan (input), proses, dan hasil (output). Di dalam pendidikan Islam, pengawasan tidak hanya mengukur dan membandingkan proses dan hasil yang dicapai semata tetapi secara keseluruhan harus sesuai dengan nilai-nilai dalam ajaran Islam. Terdapat beberapa hal yang harus diperhatikan dalam melakukan pengawasan pendidikan Islam. Pertama, pengawasan harus didasarkan pada standar yang telah ditetapkan, kedua, harus didasarkan pada indikator lulusan ketiga, pelaksanaan harus sesuai standar.

Secara filosofi, pengawasan dalam pendidikan Islam dilakukan bukan saja oleh seorang manajer atau pimpinan dalam suatu organisasi tetapi lebih dari itu, pengawasan hakiki dilakukan oleh "Sang Maha Melihat dan Maha Mengetahui : Allah SWT. Oleh karenanya pengawasan (supervisi) harus dilakukan dengan ketulusan, kejujuran dan keadilan atas fakta dan data yang ada. Hal ini telah disebutkan didalam QS. As-Shaft :3, yang artinya "Amat besar kebencian di sisi Allah bahwa kamu mengatakan apa-apa yang tidak kamu kerjakan".

Pengawasan/supervisi dalam pendidikan Islam tidak dimaksudkan untuk mencari-cari kesalahan, menakut-nakuti atau bahkan menjatuhkan sesorang atas kinerja dan eksistensinya, tetapi lebih pada upaya menunjukkan jalan yang lurus, jalan yang benar, dan upaya alternatif yang mungkin bisa dilakukan untuk meningkatkan mutu pendidikan. Pengawasan yang baik adalah pengawasan yang dilakukan sepanjang waktu (terus menerus) dan bukan sewaktu-waktu atau hanya pada termin-termin tertentu. Karena upaya peningkatan mutu pendidikan Islam sesungguhnya mengikuti 
perintah untuk menuntut ilmu sepanjang hayat. Pengawasan/supervisi dalam pendidikan Islam sangat menjunjung tinggi potensi fitrah manusia. Artinya dalam menilai kinerja seseorang harus menjunjung tinggi kelebihan dan kekurangannya sebagai hamba Allah. Penilaian tidak boleh membuat seseorang frustasi melainkan membangkitkan motivasi untuk melakukan tugas dan kewajiban yang lebih baik di masa mendatang. (Ramayulis, 2008)

\section{SIMPULAN DAN SARAN}

Sebagai wadah pembelajaran Pendidikan Islam, maka LPI harus dikelola dengan cara-cara yang efektif, efisien, dan moderen dengan tetap berpijak pada ajaran Islam. Lembaga Pendidikan Islam tidak boleh tabu dengan manajemen moderen dan bahkan sudah saatnya mengkaji ulang manajemen paternalistik yang selama ini lebih banyak mewarnai tata kelola Lembaga Pendidikan Islam. Upaya untuk mengimplementasikan dengan tepat printah Alloh SWT untuk agar Pendidikan Islam mampu melahirkan generasi terbaik (khairu ummah) harus dipahami sebagai printah untuk berikhtiar semaksimal mungkin mencari dan menerapkan berbagai strategi pemgelolaan LPI. Terdapat beberapa strategi pengelolaan Lembaga Pendidikan Islam yang dapat ditawarkan kepada para pengelola sekolah/madrasah dan LPI lainnya yaitu : Pertama, menerapkan fungsi-fungsi MPI secara konsisten dan komprehensif yang meliputi perencanaan, pengorganisasian, pelaksanaan/pengarahan, dan pengawasan. Keempat fungsi manajemen tersebut harus dilaksanakan secara terpadu dengan target menghasilkan LPI yang berkualitas yang mampu mencetak lulusan yang bermutu dan unggul. Kedua, menerapkan empat strategi pengelolaan yakni, strategi substantif, strategi bottom-up, strategi deregulatory, dan strategi cooperative.

Upaya lainnya yang juga dapat dilakukan adalah melakukan pembenahan dan pembinaan mutu SDM dan perbaikan sarana fisik lainnya. Pembinaan SDM terutama para guru/ustadz secara terus menerus menyesuaikan dengan tuntutan dan kebutuhan. Penataan sistem administrasi dan keuangan yang moderen dan amanah (akuntabilitas). Merumuskan dan mengkaji ulang visi pengembangan LPI secara berjangka sebagai "road of map" pencapaian cita-cita yang diinginkan. Melakukan pengkajian ulang dan evaluasi diri terhadap konsep dan praktik pengelolaan yang dilakukan dan meng "up date"nya sesuai kebutuhan serta tidak menjadikan sekolah'madrasah sebagai alat 
penguat kekuasaan belaka sehingga merugikan kepentingan pendidikan yang lebih besar dan mulia. 


\section{DAFTAR PUSTAKA}

Alim, N. (2010). Lembaga Pendidikan Islam. Retrieved September 5, 2017, from https://prodibpi.wordpress.com/2010/08/05/lembaga-pendidikan-islam-antararealitas-dan-kemestian-pengembangannya/

Arcaro, J. S. (2007). Pendidikan Berbasis Mutu: Prinsip-Prinsip Perumusan dan Tata Langkah Penerapan (Terj. Yosai Triantara). Yogyakarta: Pustaka Belajar.

Ardimen. (2012). Pengelolaan Lembaga Pendidikan Berbasis SNP Dalam Rangka Pencapaian Tujuan Pendidikan. Ta'dib, 15(2), 137-148.

Casteter, W. B. (1992). The Personel Function in Educational Administration. (Third Edition). New York: Mc Millan Publishing.

Chotimah, C., \& Fathurrohman, M. (2014). Komplemen Manajemen Pendidikan Islam: Konsep Integratif Pelengkap Manajemen Pendidikan Islam. Yogyakarta: Teras.

Fathurrohman, M. S. (2012). Implementasi Manajemen Peningkatan Mutu Pendidikan Islam: Peningkatan Lembaga Pendidikan Islam Secara Holistik (Praktik dan Teoritik). Yogyakarta: Teras.

Harahap, S. (1998). Perguruan Tinggi Islam di Era Globalisasi. Yogyakarta: Tiara Wacana.

Hawi, A. (2005). Kapita Selekta Pendidikan Islam. Palembang: Raden Patah Press.

Himayaturohmah, E. (2017). Strategi Pengembangan Manajemen Pengelolaan Pusat Kegiatan Belajar Masyarakat (Pkbm) Di Provinsi Riau. Jurnal Penjamin Mutu, $3(1), 100-110$.

Ibrahim, M. B. (1997). Amanah Dalam Manajemen. Jakarta: Pustaka Al Kautsar.

Khadijah, I. (2015). Manajemen Mutu Terpadu (Tqm) Pada Lembaga Pendidikan Islam. Al-Idarah: Jurnal Kependidikan Islam, 5(1), 59-75.

Khojir. (2011). Pengembangan Lembaga Pendidikan di Indonesia. Dinamika Ilmu, 11(2), 0-9.

Kurikulum, P. (2016a). Pengertian Lembaga Pendidikan Islam. Retrieved September 30, 2017, from http://portalkurikulum.blogspot.co.id/2016/10/pengertian-lembagapendidikan-islam.html

Kurikulum, P. (2016b). Prinsip-Prinsip Lembaga Pendidikan Islam. Retrieved September 30, 2017, from http://portalkurikulum.blogspot.co.id/2016/10/prinsipprinsip-lembaga-pendidikan-islam.html

Majid, A. (2012). Belajar dan Pembelajaran Pendidikan Agama Islam. Bandung: Remaja Rosdakarya.

Muhaimin, \& Mujib, A. (1993). Pemikiran Pendidikan Islam. Bandung: Trigenda Karya. 
Nata, A. (2010). Ilmu Pendidikan Islam. Jakarta: Kencana Prenada.

Priyatna, M. (2016). Manajemen Pengembangan SDM Pada Lembaga Pendidikan Islam. Edukasi Islami Jurnal Pendidikan Islam, 5(1), 1231-1250.

Qomar, M. (2007). Manajemen Pendidikan Islam. Malang: Erlangga.

Ramayulis. (2008). Ilmu Pendidikan Islam. Jakarta: Kalam Mulia.

Rohman, F. (2014). Strategi Pengelolaan Komponen Pembelajaran Bahasa Arab. Arabiyat: Jurnal Pendidikan Bahasa Arab Dan Kebahasaaraban, 1(1), 64-78.

Rozi, M. A. F. (2016). Strategi Peningkatan Mutu Pendidikan Islam. Edukasi, 4(2), $322-336$.

Rusmaini. (2014). Ilmu Pendidikan. Palembang: Grafika Telindo Press.

Sada, H. J. (2015). Pendidik Dalam Perspektif Al-Qur'an. Al-Tadzkiyyah: Jurnal Pendidikan Islam, 6(1), 93-105.

Sodiah. (2016). Manajemen Lembaga Pendidikan Islam Berbasis Masyarakat Dan Sekolah. Sosial Budaya, 13(1), 89-100.

Sulistyorini, M. F. (2012). Implementasi Manajemen Peningkatan Mutu Pendidikan Islam: Peningkatan Lembaga Pendidikan Islam Secara Holistik (Praktik dan Teoritik). Yogyakarta: Teras.

Tanu, I. K. (2016). Pembelajaran Berbasis Budaya Dalam Meningkatkan Mutu Pendidikan di Sekolah. Jurnal Penjamin Mutu, 2(1), 34-43.

Wahyuni, S. (2014). Lembaga Pendidikan Islam. Retrieved from http://duniapendidikan33.blogspot.co.id/2014/12/lembaga-pendidikan-islam.html 